\title{
PV HYBRID VRLA BATTERY TEST RESULTS FROM A TELECOMMUNICATIONS SITE
}

\author{
Thomas D. Hund and John W. Stevens \\ Sandia National Laboratories, PO Box 5800 \\ Albuquerque, New Mexico 87185-0753
}

\begin{abstract}
A new valve regulated lead-acid (VRLA) gel motive power battery and PV system power center have been tested in the laboratory and at a PV hybrid telecommunication site. The power center provides battery charge control, system remote communications, and data acquisition at the field test site. Extensive laboratory and field-test data were used to improve battery performance by optimizing. regulation voltages, finish-charge, and system design. After 1.5-years of service, battery and charge controller performance have met all performance requirements for the remote communications site at Sandia National Laboratories.
\end{abstract}

\section{INTRODUCTION}

The Mt. Washington communication site near Sandia National Laboratories was established more than 25 years ago and was powered by an ac cable laid over a quarter of a mile of very steep rugged mountainous terrain. The theory was that this cable would be replaced with an overhead line at some future date. The area traversed by the cable recently became a training ground for military personnel, presenting a hazard both to the cable and the personnel. Sandia's Facilities staff estimated the cost to install an overhead line up the mountain, and Sandia's Photovoltaic Systems Assistance Center (PVSAC) provided a cost estimate for serving the site with photovoltaics. The solar option was about half the cost of a line installation, so the Facilities group asked the PVSAC to assist it in preparing a bid package and in evaluating proposals. Direct Power and Water, an Albuquerquebased photovoltaic systems designer/installer, was awarded a contract to install a photovoltaic hybrid system, which began operation in March of 1999 (see Fig. 1).

\section{TEST OBJECTIVES FOR THE SYSTEM}

The Mt. Washington site is being monitored to evaluate the performance of the new Deka valve-regulated lead-acid (VRLA) G-75 gel battery and the Digital Solar MPR-9400 system charge controller and power center. Previous experience with photovoltaic systems identified the battery and charge controller as the source of the most common performance and life-cycle cost drivers $[1,2]$. The evaluation is part of an effort to improve system design, charging strategies, battery technology for photovoltaic systems and reduce life-cycle cost using both laboratory and field test data.

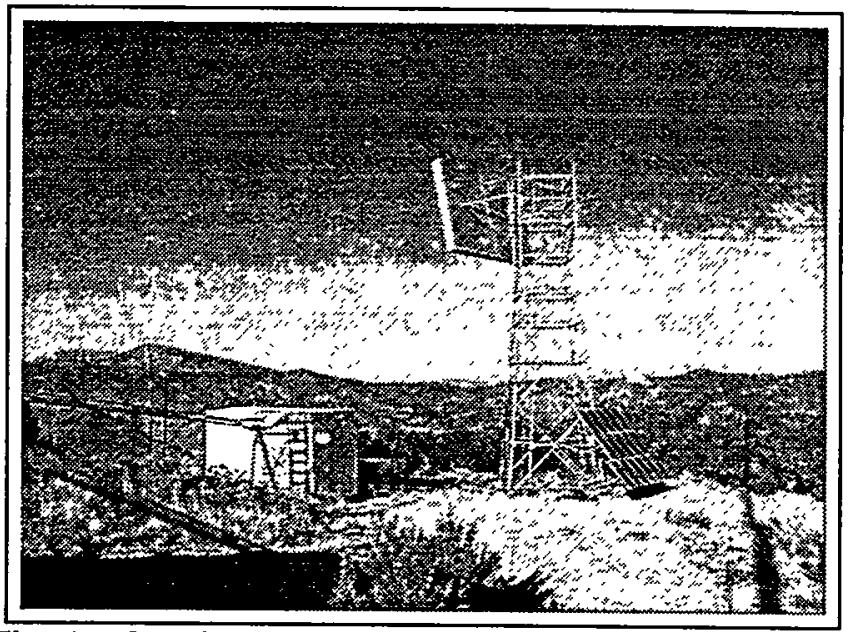

Fig. 1. Sandia's Mt. Washington Telecommunication Site.

\section{DESIGN OF THE SYSTEM}

The Mt. Washington telecommunication site is designed to be a stand-alone 48-volt DC system with an engine generator backup for emergency power. The loads consist of DC to DC converters for 12-volt radio transmitters, a 48-volt microwave phone, and a small $A C$ inverter for $120 \mathrm{~V}$ lighting and room cooling fan. PV power is provided by three Solec 48-volt photovoltaic arrays at $50^{\circ}$ tilt for a peak power of 1,600 watts. The PV array provides more than enough power for the 50 amp-hours (Ah) load even during the minimum solar resource month. The site has a conservative energy design to ensure adequate battery charging and minimal generator run time. With an average December solar resource at tilt for Albuquerque of $5.5 \mathrm{kWh} / \mathrm{m}^{2}$, the photovoltaic array is calculated to provide an average of 129 Ah/day in December. Based on the above solar and load Ah numbers, the minimum system array $A h$ to load $A h$ ratio is calculated to be about 1.6. The array-to-load Ah ratio is important to determine available energy for battery recovery and finish-charge. In this case the battery will spend about $6-\mathrm{h}$ at regulation voltage on a clear day. At array-to-load ratios significantly below 1.3 , battery recovery and finish-charge has been shown to be marginal (see Fig. 4) because it will spend less than $3-h$ at regulation voltage on a clear day. 


\section{DISCLAIMER}

This report was prepared as an account of work sponsored by an agency of the United States Government. Neither the United States Government nor any agency thereof, nor any of their employees, make any warranty, express or implied, or assumes any legal liability or responsibility for the accuracy, completeness, or usefulness of any information, apparatus, product, or process disclosed, or represents that its use would not infringe privately owned rights. Reference herein to any specific commercial product, process, or service by trade name, trademark, manufacturer, or otherwise does not necessarily constitute or imply its endorsement, recommendation, or favoring by the United States Government or any agency thereof. The views and opinions of authors expressed herein do not necessarily state or reflect those of the United States Government or any agency thereof. 


\section{DISCLAIMER}

Portions of this document may be illegible in electronic image products. Images are produced from the best available original document. 


\section{System Power Center}

The PV power center manufactured by Digital Solar Technologies model number MPR- 9400 is microprocessorbased and incorporates an integrated System Control and Data Acquisition (SCADA) feature (see Fig. 2). The unit is fully programmable by the user for on/off photovoltaic battery charging, load control, generator battery charging, and data logging. Sandia National Labs has worked closely with Digital Solar to add the SCADA feature. Extensive laboratory and field testing was conducted to improve and debug battery charging algorithms using the engine generator and Ah counting charge control methods [3]. Now all system control functions can be remotely controlled through a modem connection. PV Battery charging is accomplished with three subarrays switched on and off with mercury displacement relays at the temperature compensated voltages. Temperature compensation is adjustable and in this case was set at $0.128 \mathrm{~V} /{ }^{\circ} \mathrm{C}$ or $-0.0053 \mathrm{~V} /{ }^{\circ} \mathrm{C} /$ cell. The setpoints for Mt. Washington in Table 2 were chosen based on recommendations from the battery manufacturer, array size, system loads, battery size, and Sandia's previous experience using on/off subarray switching. This was the first use of these batteries, system controller, and system design in the field; therefore, some uncertainty existed as to the most desirable setpoints. Since The MPR-9400 controller allows these setpoints to be changed remotely, regulation voltage optimization, especially the reconnect voltage can be easily accomplished. The goal in setting on/off regulation voltages is to provide maximum charge without causing a loss in voltage control due to excessively short on/off cycles. In this case, the MPR-9400 requires on/off cycles in excess of 5 to 10 seconds.

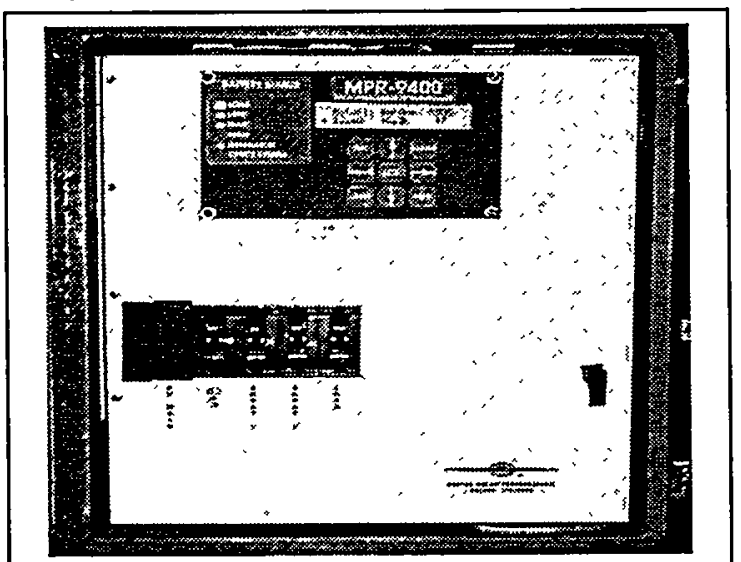

Fig. 2. Digital Solar's MPR-9400 System Power Center, Charge Controller, and SCADA system

\section{Deka G-75 Gel VRLA Battery}

The battery, a Deka 258 Ah G-75-7 VRLA gel, is an industrial motive power battery configured in two parallel strings for a total rated capacity of 516 Ah (see Fig. 3). The system load profile is primarily a continuous 3 to 4 amp load with intermittent load spikes up to about 15 amps depending on the use of the radio transmitters and $A C$ cooling fan. Normally, the total daily load is less than 80 $\mathrm{Ah}$, and the nighttime battery discharge is usually about 50 Ah or slightly less than $10 \%$ depth-of-discharge.

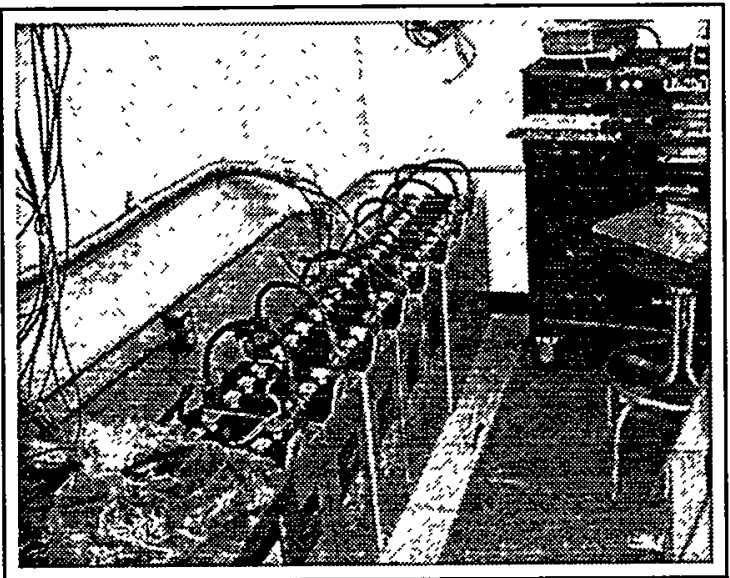

Fig. 3. Deka G-75 Gel VRLA Battery.

\section{TEST RESULTS}

Battery capacity was initially measured in February of 1999 before the system was operational (see Table 1). It was measured at $544 \mathrm{Ah}$ to $1.85 \mathrm{vpc}$ at a 25-amp rate. This capacity was greater than the 516 Ah nameplate capacity to $1.80 \mathrm{vpc}$ at the $24-\mathrm{h}$ rate. The initial battery measurements included capacity in Ah, impedance in micro-ohms, and cell voltage at the end of charge and at the end of discharge. Operation began in March 1999, and in October, a second test was conducted to obtain the operational battery capacity. The results indicated that the battery capacity was down by over $12 \%$. Table 1 lists the test results, showing that the battery capacity to $1.85 \mathrm{vpc}$ dropped from 544 Ah to 469 Ah, a 75 Ah loss in this eightmonth period. If battery capacity is temperature compensated, then this initial capacity loss is considerably more at about $18 \%$ based on the $4^{\circ} \mathrm{C}$ lower battery temperature of the initial capacity test. In addition, the maximum cell impedance increased from 1,544 to 1,817 micro-ohms, and the range in cell voltages on discharge at $1.85 \mathrm{vpc}$ increased from 0.09 volts to 0.16 volts. Both the impedance increase and the cell voltage divergence are indicators of battery capacity loss and degradation in cell health.

\section{Cause of Battery Capacity Fade}

A more detailed evaluation of battery charging requirements from laboratory testing clearly indicated that the battery was being under charged, and the cause was aftributed to a low on/off $\mathrm{PV}$ regulation voltage and a low regulation voltage of $2.33 \mathrm{vpc}$ in the engine generator battery charger. The engine generator battery charger was providing a biweekly "equalize" charge to the battery. Laboratory PV hybrid battery cycle test results [4] in Figure 4 show that the same Deka battery will-foose capacity quickly if the time between finish-charges is too long (15 to

$$
12 \leqslant e^{2}
$$


30-days), the finish-charge time is too short (<3 to $6-h)$, or the regulation voltage is too low $(<2.35 \mathrm{vpc})$. The laboratory tests have shown that the battery will maintain capacity if the minimum regulation voltage is $2.35 \mathrm{vpc}$ to $2.40 \mathrm{vpc}$ on finish-charge and the finish-charge time is a minimum of 3 to 6 -h every day. The cycle test most like the Mt. Washington PV system in Figure 4 is the 3-h or 6-h finish-charge every cycle at $2.35 \mathrm{vpc}(14.1 \mathrm{~V})$. In the above specified tests, the battery capacity quickly drops $10 \%$ and then slowly fades in capacity using the 3-h finishcharge or maintains initial capacity with the 6-h finishcharge.

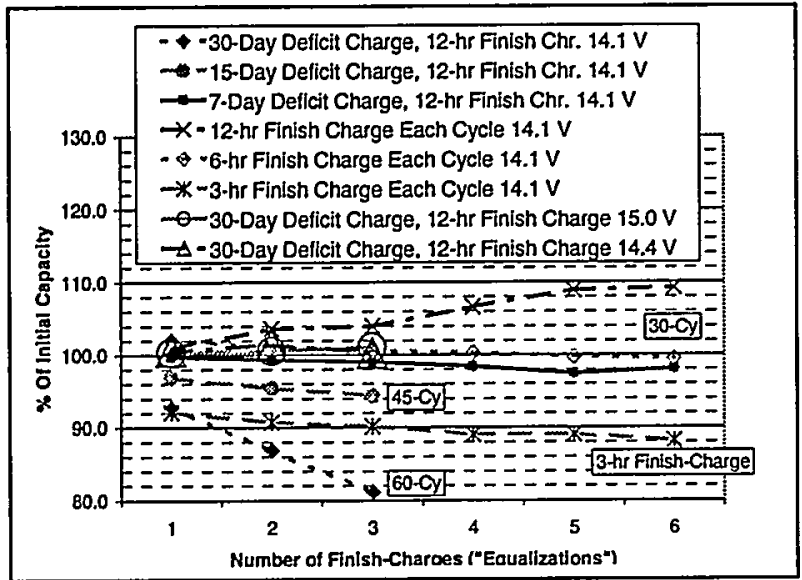

Fig. 4. Laboratory PV Hybrid Test Results From The Deka G-75 VRLA Gel Battery.

The average battery voltage using on/off regulation at Mt. Washington was about $2.31 \mathrm{vpc}(55.4 \mathrm{~V})$ and the biweekly "equalize" charge only charged to $2.33 \mathrm{vpc}$. The battery manufacturer recommended a temperature compensated regulation voltage of between 2.35 and 2.40 vpc. The low regulation voltage is significant because of the limited time available for charging.

\section{Deka VRLA Gel Battery Venting}

Laboratory battery cycling tests in Figure 4 at 2.40 and $2.50 \mathrm{vpc}$ constant voltage indicated that the 30-day deficit-charge capacity loss could be prevented using the higher regulation voltages. In a stand-alone application the higher regulation voltage could reduce the time required to finish-charge the battery, thus improving system performance if battery cycle-life could be maintained. A potential problem with a higher regulation voltage is the increased venting rate from the Deka VRLA gel battery. All
VRLA batteries vent when the internal gassing rate of the cell exceeds the rate at which the oxygen can be reused in the oxygen recombination cycle during charge. Any venting results in water loss, which is an important factor in the reduction of VRLA battery cycle-life. Venting rate measurements on the Deka gel batteries in the laboratory using constant voltage charging have shown that the normally very low venting rate at 2.35 vpc only increases by about $15 \%$ at $2.40 \mathrm{vpc}$, while at $2.50 \mathrm{vpc}$, the venting rate increases by more than $400 \%$. Since the increase in venting at $2.40 \mathrm{vpc}$ is minimal, the potential benefits of improved charging, such as less time required at regulation voltage and improved battery health, compensate for the relatively small increase in venting and potential loss in cycle-life.

In addition to tests using constant voltage charging, laboratory venting rate measurements using two subarrays with on/off charge control resulted in a much lower venting rate than constant-voltage charging at the disconnect voltage. The volume of gas vented using an array disconnect of 2.42 and $2.40 \mathrm{vpc}$ and a reconnect of 2.32 and $2.31 \mathrm{vpc}$ was nearly zero compared to the venting during the daily charge at a constant voltage of 2.35 vpc. The laboratory test results clearly show that when using on/off charge control, the venting rate is much lower than would be seen using a constant-voltage charge at the upper disconnect voltage.

\section{New Setpoints for Deka Gel Battery}

The new subarray on/off setpoints for Mt. Washington are in Table 2 and were increased from about 2.35 to 2.40 vpc (56.40 to $57.68 \mathrm{~V})$ disconnect voltage and 2.30 to 2.32 vpc $(55.20$ to $55.68 \mathrm{~V})$ reconnect voltage. Figure 5 shows the 15-minute average battery voltages during charging for the Mt. Washington battery in addition to the battery temperature and the temperature-compensated charge voltage at 2.35 and $2.40 \mathrm{vpc}$. As seen in Figure 5, the old setpoints charged the battery to an average voltage well below the required temperature-compensated value, and the new setpoints charge the battery to an average voltage slightly above the minimum required temperaturecompensated value of 2.35 vpc. In addition to the higher subarray control voltages, the programmed enginegenerator "equalize" interval was eliminated. The new subarray control voltages provide the minimum required finish-charge more effectively while eliminating unnecessary fuel consumption and generator run time.

\begin{tabular}{|c|c|c|c|c|c|c|c|c|c|c|c|}
\hline \multirow[b]{2}{*}{ Test Date } & \multicolumn{2}{|c|}{ Battery Capacity in Ah } & \multicolumn{3}{|c|}{$\begin{array}{c}\text { Alber Cell Impedance } \\
\text { in micro-Ohms }\end{array}$} & \multicolumn{3}{|c|}{ Cell Volts on Charge } & \multicolumn{3}{|c|}{$\begin{array}{c}\text { Cell Volts @ } 25 \text { A } \\
\text { Load }\end{array}$} \\
\hline & 25 A Load to $1.85 \mathrm{vpc}$ & Temp. C & Min & Max & Av. & Min & $\operatorname{Max}$ & Av. & $\operatorname{Min}$ & Max & Av. \\
\hline $02 / 17 / 1999$ & 544 & 17 & 1110 & 1544 & 1310 & 2.26 & 2.31 & 2.28 & 1.83 & 1.92 & 1.87 \\
\hline $10 / 30 / 1999$ & 469 & 21 & 1072 & 1817 & 1335 & NA & NA & NA & 1.72 & 1.88 & 1.84 \\
\hline $05 / 25 / 2000$ & 508 & 25 & 976 & 1579 & 1267 & 2.28 & 2.32 & 2.30 & 1.77 & 1.90 & 1.85 \\
\hline $08 / 18 / 2000$ & 489 & 24 & 1047 & 1580 & 1280 & 2.28 & 2.33 & 2.31 & 1.75 & 1.91 & 1.85 \\
\hline $08 / 18 / 2000$ & 510 to 1.80 vpc & 24 & 1047 & 1580 & 1280 & 2.28 & 2.33 & 2.31 & 1.75 & 1.91 & 1.85 \\
\hline
\end{tabular}

Table 1. Mt. Washington Deka G-75 VRLA Gel Battery Capacity, Impedance, and Cell Voltage Test Results 


\begin{tabular}{|r|c|c|}
\hline Relay\# & $\begin{array}{c}\text { Disconnect } \\
\text { vpc/Voltage }\end{array}$ & $\begin{array}{c}\text { Reconnect } \\
\text { vpc/Voltage }\end{array}$ \\
\hline \hline Old HVD-1 & $2.355 / 56.52$ & $2.302 / 55.24$ \\
\hline New HVD-1 & $2.403 / 57.68$ & $2.320 / 55.68$ \\
\hline Old HVD-2 & $2.350 / 56.40$ & $2.290 / 54.96$ \\
\hline New HVD-2 & $2.398 / 57.56$ & $2.312 / 55.48$ \\
\hline Old HVD-3 & $2.342 / 56.20$ & $2.282 / 54.76$ \\
\hline New HVD-3 & $2.390 / 57.36$ & $2.300 / 55.20$ \\
\hline
\end{tabular}

Table 2. Mit. Washington PV Array Shedding Setpoints For The Deka VRLA Gel Battery

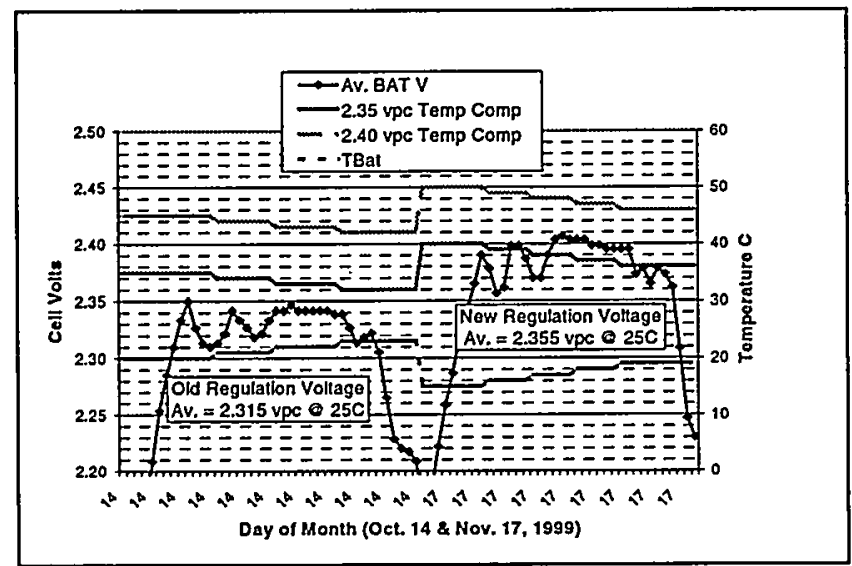

Fig. 5. Battery Regulation Voltage With Old and New Setpoints.

\section{New Test Results}

In Table 1 are the last two capacity tests in May and August of 2000 with the new setpoints from Table 2. The results show an increase in capacity to 508 and 489 Ah from the low capacity measurement of $473 \mathrm{Ah}$. In addition, the maximum cell impedance dropped to 1,579 and 1,580 from the high value of 1,817 micro-ohms and the cell voltage range was measured at 0.13 and 0.16 volts from the high value of 0.16 volts. The new capacity measurements clearly show a halt to the capacity fade and some capacity recovery. The cell measurements are improved with respect to impedance, and are stable with respect to the cell voltage divergence. These battery test results indicate that the capacity fade and cell deterioration was halted by the increased regulation voltage.

\section{SUMMARY}

The Mt. Washington telecommunication site near Sandia National Laboratories with the new Deka G-75 VRLA gel battery technology and MPR-9400 power center and system controller have provided an important opportunity to evaluate the design of a photovoltaic system with this new technology. Both field and laboratory work are critical in understanding PV system and battery needs, capabilities, and limitations. The results of this work are as follows:
1) The Deka G-75 gel VR्LA motive power battery since the initial capacity fade has recovered some capacity and should continue to operate with minimal capacity loss using the new on/off regulation voltages. After the last capacity test the battery was at about $96 \%$ of its factory rated capacity to $1.80 \mathrm{vpc}$ and about $84 \%$ of its initial temperature compensated capacity to 1.85 vpc.

2) With the aid of initial laboratory testing for debugging, the MPR-9400 power center is now providing reliable system control, battery charging, and remote system command and control and data acquisition (SCADA). The SCADA system minimizes costly site visits while allowing for site control and performance monitoring.

3) Conservative PV system energy design has proven to be critical in providing adequate battery finish-charging for the Deka G-75 gel VRLA battery while allowing the elimination of the long engine generator finish-charge or "equalize" charge. The only source for generator run time has been a bimonthly 20-minute generator exercise. This has minimized the transportation of fuel to the mountain top and greatly reduced generator maintenance.

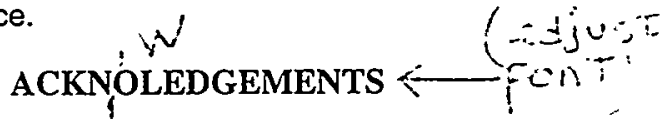

The authors would like to acknowledge the contract work funded by Sandia and implemented by the Florida Solar Energy Center to develop the SCADA system for the Digital Solar's MPR- 9400 power center. This was an important upgrade for the Digital Solar Power Center. In addition, the support of East Penn Manufacturing or Deka Battery was very useful in identifying battery-charging requirements.

\section{REFERENCES}

[1] Woodworth, J.R., Harrington, S.R., Dunlop, J.D., et al, "Evaluation of the Batteries and Charge Controllers in Small Stand-alone Photovoltaic Systems", First World Conference on Photovoltaic Energy Conversion, Hawaii, Dec. 1994. hitp://www.sandia.gov/pv/lib/bospub.htm

[2] Tom Hund, "Capacity Loss in PV Batteries and Recovery Procedures", Sandia National Labs web site, Photovoltaic System Applications Dept., http://www.sandia.gov/pv/bos/batteries.htm

[3] T. D. Hund, B. Thompson, "AMP-HOUR COUNTING CHARGE CONTROL FOR PHOTOVOLTAIC HYBRID POWER SYSTEMS", IEEE PVSC, Sept. 1997, pp. 12811284. http://www.sandia.gov/pv/lib/bospub.htm

[4] T.D. Hund, "PV Hybrid Battery Testing", NREL NCPV Program Review Meeting, April 17, 2000. http://www.sandia.gov/pv/ncpvprm.htm 